\title{
CORAK PEMIKIRAN DAKWAH MOHAMMAD NATSIR
}

\author{
Sugianto \\ IAI An-Nur Lampung \\ Alamat: Desa Sidoarjo Kec. Jati Agung Kab. Lampung Selatan e-mail: \\ stai_annur10@yahoo.com. Telp. 181879221119, Kode Pos.35865 \\ Sugiantoalfaruqi3@gmail.com
}

\begin{abstract}
This written discussed thought of Mohammad Natsir. The method applied to discusse thought of Mohammad Natsir was literature review through books or article which concern object researched or document supporter, such as, journal and article. This written was used text study with used perspective hermeneutic to interpretation disgn of his thought. The result of reseach was that through dakwah of Muhammad Natsir was religious-politic.
\end{abstract}

Key Word: Religius, Politic and Dakwah

\begin{abstract}
Abstrak
Tulisan ini mengkaji pemikiran Mohammad Natsir. Metode yang digunakan dalam mengkaji hasil pemikiran Mohammad Natsir adalah kajian literatur (kajian pustaka) melalui buku-buku atau literatur terkait dengan obyek yang diteliti atau dokumen pendukung seperti jurnal dan artikel terkait. Tulisan ini menggunakan studi teks dengan menggunakan paradigma hermeneutika untuk menafsirkan corak pemikirannya. Hasil kajian menunjukkan bahwa pemikiran dakwah Mohammad Natsir lebih bercorak religius-politik.
\end{abstract}

Kata Kunci: Religious, Politik dan Dakwah

\section{PENDAHULUAN}

Tidaklah berlebihan jika banyak pengamat memprediksikan bahwa kebangkitan Islam akan muncul di ufuk timur. Cercah cahaya keislaman mulai tampak dengan relanya kekuatan gebyar aktivitas keislaman merebak di mana-mana. ${ }^{1}$

Gerakan Islam di masa lampau ataupun sekarang banyak memberikan hikmah kepada kita. Alangkah ruginya umat Islam pada masa yang telah lalu, yang sering dizalimi oleh para anggota aktivis pergerakan sendiri, yang tidak mengetahui inti perjuangan dari sebuah gerakan. Setelah kemenangan tercapai, mereka berusaha menawarkan beberapa konsep untuk mengatur negara yang sedikit banyak keluar dari apa yang diharapkan oleh aktivis gerakan Islam sejati.

Nama Mohammad Natsir begitu penting di era pergerakan nasional dan awal kemerdekaan Indonesia. Tokoh yang di era 1930-an ini sering beradu pemikiran dengan Soekarno, iamerupakan tokoh yang selalu menginspirasi. Konsistennya memperjuangkan Negara Islam melalui Masyumi yang sudah sering kita dengar. Kali ini penulis mencoba mereview kembali pemikiran-pemikiran beliau baik kiprahnya di bidang pendidikan, dakwah ataupun dalam kenegaraan.

Beliau dikenal sebagai pahlawan nasional yang kiprahnya dalam memajukan bangsa ini, khususnya umat Islam, di waktu lampau telah diakui oleh berbagai

1 Abied, Aunul Shah M. et al. Islam Garda Depan; Mosaik Pemikiran Islam Timur Tengah. Cet. I.( Mizan: Bandung, 2001),

Received : Agustus 20, 2019, Revised : Oktober 15, 2019, Accepted : Januari 17, 2020

Alamat: Desa Sidoarjo Kec. Jati Agung Kab. Lampung Selatan e-mail: stai_annur10@yahoo.com.

Telp. 081879221119, kode Pos.35865

Email : sugiantoalfaruqi3@gmail.com 
kalangan. Bahkan, pengaruh dari usaha beliau masih dirasakan hingga sekarang. Pak Natsir (sapaan akrab beliau) tidak hanya dikenal sebagai sosok negarawan, pemikir modernis, mujahid dakwah. Tapi, beliau dikenal juga sebagai seorang aktivis pendidik bangsa yang telah menorehkan episode sejarahnya di Indonesia, sejak awal kemerdekaan hingga masa Orde Baru. Pemikirannya banyak digali dan dijadikan sebagai titik tolak kebangkitan umat Islam dalam berbagai macam bidang.

Mohammad Natsir adalah tokoh yang menggagas pembaharuan pendidikan Islam yang berbasis al-Qur'an dan al-Sunnah. Dengan berbasis al-Qur'an dan alSunnah, maka pendidikan Islam harus bersifat integral, harmonis, dan universal, serta mengembangkan segenap potensi manusia agar menjadi manusia yang bebas, mandiri sehingga mampu melaksanakan fungsinya sebagai khalifah di muka bumi. Konsep pendidikan yang integral, harmonis dan universal tersebut oleh Natsir dihubungkan dengan misi ajaran Islam sebagai agama yang bersifat universal. Dari latar belakang di atas maka penulis fokus pada corak pemikiran dakwah yang di gagas oleh Mohammad Natsir.

\section{PEMBAHASAN}

\section{Biografi Moh. Natsir}

Mohammad Natsir adalah salah satu tokoh yang begitu penting dalam wacana pemikiran dan garakan dakwah di Indonesia. Ia adalah seorang negarawan dan pelaku sejarah negara Indonesia modern. Selain pemikir, ia juga seorang politikus. Ia sebagai tokoh yang low profile ini pernah memimpin Partai Politik Islam (PII) dan Masyumi. Sebagai negarawan, ia pernah menjadi perdana menteri di zaman Soekarno. Kegiatan terakhirnya adalah bergelut di bidang dakwah. Ia adalah seorang pelopor berdirinya organisasi Dewan Dakwah Islamiyah Indonesia (DDII). Ia juga menjadi jembatan bagai hubungan yang luas dengan dunia Islam internasional. ${ }^{2}$

Natsir dilahirkan di Alahan Panjang, Solok, Sumatera Barat pada tanggal 17 Juli 1908. Kedua orangtuanya berasal dari Maninjau. Ayahnya bernama Idris Sutan Saripado, seorang pegawai pemerintah dan pernah menjadi asisten demang di Bonjol. Natsir adalah anak ketiga dari empat bersaudara. Pada waktu kecil, Natsir sekolah di SD Pemerintah di Maninjau, kemudian melanjutkan ke HIS milik pemerintah di Solok, HIS Adabiyah di Padang HIS Solok dan kembali ke HIS pemerintah di Padang. Natsir kemudian melanjutkan studinya di Mulo Padang dan melanjutkan ke AMS A 2 (SMA jurusan sastra Barat) di Bandung. Walaupun mendapatkan tawaran beasiswa dari Mulo dan AMS untuk belajar di Fakultas Hukum di Jakarta atau Fakultas Ekonomi di Rotterdam, ia tidak melanjutkan studinya dan lebih tertarik pada perjuangan Islam.

Pendidikan agamanya diperoleh dari pendidikan orangtua, kemudian ia masuk sekolah diniyah di Solok pada sore hari dan belajar mengaji al-Qur'an pada malam harinya di surau. Pengetahuan agama Natsir semakin mendalam ketika ia berguru kepada Ustadz Abbas Hasan, seorang tokoh Persatuan Islam (Persis) di Bandung. Kepribadian A. Hasan yang hidup sederhana dan rapi dalam bekerja, alim, tajam argumentasinya dan berani mengemukakan pendapat tampaknya cukup berpengaruh terhadap kepribadian M. Natsir.

Natsir banyak belajar mengenai teologi (tauhid), ilmu fikih (syari' ah), tafsir hadits, filsafat, sejarah, kebudayaan dan politik Islam. Di samping itu, ia juga banyak belajar

2 Didin Saefudin, Pemikiran Modern dan Post Modern Islam (Jakarta: Gramedia Widia Sarana Indonesia, 2003), h. 209. 
dari tokoh-tokoh Islam terkemuka pada waktu itu seperti H. Agus Salim, Syekh Ahmad Soorkati, HOS Cokroaminoto dan A.M. Sangaji. Pengalaman ini semua memperkokoh keyakinan M. Natsir untuk berjuang dalam menegakkan agama Islam. ${ }^{3}$

Kepribadian yang sederhana dari guru-gurunya kemudian ia ikuti dalam kehidupan kesehariannya. Ini dapat dilihat pada saat menjabat sebagai menteri Penerangan dan ketua Partai Masyumi. Demi perjuangan ia tidak sempat memikirkan untuk memiliki rumah sendiri, bahkan ketika mobilnya rusak ia service sendiri. ${ }^{4}$ Natsir juga dikenal sebagai seorang mujahid dakwah, pemimpin sejati, pendidik dan juga pejuang kemanusiaan. ${ }^{5}$ Keprihatinan dakwahnya bukan saja dirasakan dan dihargai oleh bangsa Indonesia dan umat Islam yang tersebar di seluruh Indonesia, tetapi dicintai dan dihormati umat Islam di seluruh dunia. ${ }^{6}$

\section{Pemikiran Dakwah Moh. Natsir Islam dan Negara}

Berbicara tentang hubungan Islam dan negara, Mohammad Natsir memiliki pandangan yang sangat moderat. Sebuah negara akan dikatakan bersifat Islam bukan karena secara formal disebut "negara Islam", tetapi negara itu disusun sesuai dengan ajaran-ajaran Islam, baik dalam teori maupun praktiknya. Dasar-dasar negara ini dapat dirumuskan dalam klausul- klausul yang bersifat umum sepanjang mencerminkan kehendak-kehendak Islam. Lebih lanjut, ia mengatakan bahwa Indonesia adalah negara yang jumlah pemeluk Islamnya mayoritas dan Islam memiliki ajaran yang sempurna bagi kehidupan negara dan masyarakat sekaligus Islam menjamin keragaman hidup antargolongan dalam negara dengan penuh toleransi.7 Karena itulah, Islam harus menyatu dengan negara.

Menurut Natsir, Islam tidak dapat dipisahkan dari negara. Ia mengatakan bahwa urusan kenegaraan pada pokoknya merupakan bagian integral dari risalah Islam. Dinyatakan pula bahwa kaum Muslimin mempunyai falsafah hidup atau ideologi sebagaimana agama-agama yang lainnya. Ia menyitir sebuah ayat al-Qur'an yang artinya "Tidak sekali-kali aku jadikan jin dan manusia kecuali untuk beribadah kepada-Ku". Bertolak dari dasar ideologi Islam ini, ia berkesimpulan bahwa cita-cita hidup seorang muslim di dunia ini hanya ingin menjadi hamba Allah agar mencapai kejayaan di dunia dan akhirat. 8

Untuk mencapai predikat hamba Allah tersebut, Allah memberikan aturan kepada manusia tentang cara berhubungan dengan Allah dan berhubungan dengan sesama manusia (makhluk). Dalam hubungan yang kedua inilah yang dinamakan dengan urusan kenegaraan.

Munculnya kelompok-kelompok yang tidak sepakat dengan berdirinya negara Islam, yaitu negara yang menyatukan agama dengan politik, sebenarnya karena ketidakpahaman dan kekeliruan mereka dalam memahami gambaran pemerintahan Islam itu sendiri. Kalau agama dan negara ini bersatu seakan-akan bahwa negara

${ }^{3}$ Baca dalam http:// shofwankarim.multiply.com/journal/item/49 13/11/2008.

${ }^{4}$ Amien Rais, “M. Natsir the Second Grand Old Man”, dalam Pak Natsir 80 Tahun (Jakarta: Media Dakwah, 1988), h.

75.

5 Didin Saefudin, Pemikiran Modern, h. 212.

${ }^{6}$ Didin Saefudin, Pemikiran Modern, h. 212.

7 Didin Saefudin, Pemikiran Modern, h. 214.

${ }^{8}$ Semua kegiatan hamba Allah, baik yang berupa ibadah maupun muamalah, semua itu dilakukan dalam rangka persembahannya kepada Allah Swt dengan niat (motif) mencari keridlaann-Nya semata-mata. Ini artinya menyembah Allah sebagai tujuan hidup. Baca Mohammad Natsir, Fighud Da'wah (Jakarta: Media Dakwah, 2000), h. 25.

Received : Agustus 20, 2019, Revised : Oktober 15, 2019, Accepted : Januari 17, 2020

Alamat: Desa Sidoarjo Kec. Jati Agung Kab. Lampung Selatan e-mail: stai_annur10@yahoo.com.

Telp. 081879221119, kode Pos.35865

Email : sugiantoalfaruqi3@gmail.com 
bagaikan kerajaan yang rajanya hanya duduk duduk di singgasana dan dikelilingi oleh dayang-dayangnya. Kemudian tunjuk sana-tunjuk sini sesuai dengan kemauannya. Gambaran seperti inilah yang terdapat dalam pandangan Soekarno pada waktu itu.

Jika ingin memahami hubungan agama dan negara secara jernih, hendaklah menghapuskan terlebih dahulu gambaran yang keliru tentang negara Islam. Coba tengok sejarah Turki, pada masa pemerintahan para sultan dan kekhalifahan Usmaniyah terakhir, bukanlah negara atau pemerintahan Islam. Hal itu disebabkan pemimpinnya menindas dan membiarkan masyarakatnya berada pada kebodohan. Mereka memakai Islam dan segala bentuk ibadah-ibadahnya hanya sebagai tameng belaka. ${ }^{9}$

\section{Eksistensi Negara}

Menurut Natsir, negara adalah alat bagi Islam untuk melaksanakan hukumhukum Allah demi keselamatan dan kesentosaan manusia. Sebagai alat, eksistensi negara itu bersifat mutlak. Dengan begitu, ajaran Islam dapat dilaksanakan dalam kehidupan nyata. Negara di sini bukanlah menjadi tujuan akhir, tetapi hanyalah alat untuk merealisasikan aturan-aturan Islam yang terdapat dalam al-Qur'an dan asSunah. Di antara aturan-aturan Islam tersebut, Natsir menyebutkan bahwa kewajiban berzakat, pemberantasan perzinahan dan lain-lainnya tidak akan memiliki arti apaapa manakala tidak ada negara. Eksistensi negara merupakan keharusan di dunia ini, bahkan di zaman apapun. ${ }^{10}$

\section{Politik sebagai Media Dakwah}

Untuk kasus Indonesia, adanya modernisasi politik Islam adalah sebuah keharusan. Menurut M. Natsir, modernisasi politik Islam ini merupakan sikap dan pandangan yang berusaha untuk menerapkan ajaran dan nilai-nilai keruhanian, sosial dan politik Islam yang terkandung di dalam al-Qur'an dan Sunnah yang disesuaikan dengan perkembangan mutakhir dalam sejarah peradaban manusia. Dalam term politik ini, ia mewajibkan setiap umat Islam untuk berpolitik sebagai sarana dakwah Islam.

Politik sebagai sarana dakwah berarti aturan-aturan main politik itu harus paralel dengan aturan main dakwah. Ini juga berarti bahwa politik tidak boleh menyesatkan, tidak boleh menjungkirbalikkan kebenaran dan mengelabui masyarakat. Selain itu, keterbukaan, kejujuran, rasa tanggung jawab serta keberanian untuk menyatakan bahwa yang benar itu adalah benar dan yang batil itu adalah batil harus menjadi ciri politik yang berfungsi sebagai sarana dakwah. ${ }^{11}$

Dengan memiliki ciri-ciri di atas, politik baru akan fungsional terhadap tujuan dakwah. Sebaliknya, jika aturan main politik tidak sejalan dengan aturan main dakwah, maka dapat diperkirakan bahwa politik yang semacam itu akan

\footnotetext{
${ }_{9}$ Baca dalam pemikiran M. Natsir tentang Agama dan Negara pada http:/ / baitulmaalhidayatullah.com/content/view/117/97/ 08 July 2008.

${ }_{10}$ Baca dalam pemikiran M. Natsir tentang Agama dan Negara pada http:/ / baitulmaalhidayatullah.com/content/view/117/97/ 08 July 2008.

11 Abdul Munir Mulkhan, Ideologisasi Gerakan Dakwah Episod Kehidupan M. Natsir dan Azhar Basyir (Yogyakarta: Sippress, 1996), h. 193.
} 
disfungsional terhadap dakwah. ${ }^{12}$

Politik yang dijalankan oleh seorang muslim yang berfungsi sebagai sarana dakwah bukanlah politik yang sekuler, melainkan politik yang penuh komitmen terhadap Allah. Ini juga berarti politik bukan menjadi tujuan utama untuk mencari kekuasaan demi kekuasaan atau kepentingan demi kepentingan belaka. Kekuasan, pengaruh, kepentingan, posisi politik, hanyalah menjadi sarana atau tujuan antara untuk mencapai tujuan yang sesungguhnya yaitu sebuah pengabdian kepada Allah.

\section{Islam dan Pancasila}

Pancasila adalah landasan dan falsafah Negara Kesatuan Republik Indonesia (NKRI) yang terdiri dari: Ketuhanan Yang Maha Esa; Kemanusiaan Yang Adil dan Beradab; Persatuan Indonesia; Kerakyatan yang Dipimpin Oleh Hikmat Kebijaksanaan dan Permusyawaratan Perwakilan; dan Keadilan Sosial Bagi Seluruh Rakyat Indonesia. Dilihat dari sila-sila di atas secara isi, terdapat kesesuaian antara Islam dan Pancasila. Walaupun demikian, tidak berarti bahwa Pancasila adalah Islam, atau Islam adalah Pancasila. Menurut M. Natsir, Islam lebih luas daripada lima sila di dalam Pancasila. Lima sila itu hanyalah menggambarkan sebagian dari ajaran Islam. ${ }^{13}$

Sangatlah keliru jika ada kalangan yang mempertentangkan antara Islam dan pancasila karena memang tidak ada yang perlu dipertentangkan di antara keduanya. Justru sila-sila yang terdapat dalam Pancasila adalah di antara tujuan-tujuan yang ada dalam ajaran Islam. Sila pertama "Ketuhanan Yang Maha Esa" adalah pancaran tauhid. Sila kedua "Kemanusiaan Yang Adil dan Beradab" merupakan salah satu unsur utama dari nilai-nilai keadilan masyarakat dalam Islam. Sila "Persatuan" merupakan satu sendi ajaran Islam. ${ }^{14}$ Sila "Kerakyatan" dilukiskan dalam musyawarah di dalam al-Qur'an dan Sila "Keadilan Sosial" menjadi sasaran pembentukan masyarakat marhamah menurut Islam yang harus dipraktikkan dengan perasaan kasih dan sayang.

\section{Corak Dakwah Mohammad Natsir}

Berdasarkan paparan di atas dapat di ambil sebuah benang merah mengenai corak dakwah yang dikembangkan Moh. Natsir dalam menyebarkan ide-ide gagasannya tentnag dakwah islamiyah di Indonesia.

Adapun corak dakwah beliau yaitu meleburkan antara agama dengan Negara berdasarkan nilai-nilai subtansi ajaran agama islam. Pernyataan tersebut sesuai dengan istilah yang Beliau buat yaitu Negara demokrasi islam,15 dalam ungakapan berikut: "Negara yang berdasarkan islam bukanlah teokrasi, melainkan ia adalah Negara Demokrasi, ia juga bukan Negara sekuler, ia adalah Negara Demokrasi Islam. ${ }^{16}$ Beliau mengontraskan model Negara ini dengan teokrasi, pemerintahan oleh Tuhan, dan Negara sekuler, pemerintahan tanpa Tuhan. Model yabg beliau buat merupakan

12 Politik sebagai alat dakwah harus dapat menunjang rekonstruksi masyarakat berdasarkan Islam. Rekonstruksi masyarakat itu dapat dilakukan dalam segala bidang, baik sosial, budaya, ekonomi, Iptek dan juga politik. Pengelola tugastugas kenegaraan di bidang eksekutif, legislatif dan yudikatif dan juga masyarakat luas harus bersendikan pada tauhid dan harus diwarnai dengan spirit dakwah Ilallah.

13 Yusril Ihza Mahendra, Modernisme dan Fundamentalisme dalam Politik Islam (Jakarta: Paramadina,1999), h. 136.

${ }^{14}$ Baca"Legalitas Syariat Islam" dalam http:/ / blogislami.dagdigdug.com/abaut/ul/2008.

${ }_{15}$ Mohammad Natsir adalah tokoh penting baik dalam wacana intelektual tentang Islam maupun dalam sejarah politik di Indonesia pada umumnya. Dia menyumbang pada perdebatan seputar isu-isu Islam sejak masa prakemerdekaan, ketika dia dan Soekarno mendiskusikan isu Islam dan nasionalisme. Setelah kemerdekaan, dia menjadi Menteri dan kemudian Perdana Menteri. Saya akan membahas pemikiran Natsir pada Bab 3.

${ }^{16}$ Mohammad Natsir, Islam Sebagai Dasar Negara (Jakarta: DDII, 2000), h. 89. 
sintesis dari antara dua model yang ekstream. Seperti tampak jelas pada kutipan di atas, Natsir menganggap Negara Demokrasi pada intinya baik, tapi belum cukup baik untuk diperbandingkan dengan system politik islam. Yang beliau maksutkan dengan sistem politik islam adalah sistem yang mencakup segala aspek kehidupan muslim. Islam dianggap sebagian besar penganutnya sebagai komprehensif (kamil), serba inklusif (shamil), dan cocok untuk segala zaman dan tempat (salih li kulli zaman wa makan). Pendeknya, ia adalah sistem kehidupan komplet. Dengan karakter superior ini, islam tidak bias ditundukan kebawah sistem yang lain manapun. Karena itu, semua ideology dan konsep yang dating daari luar Islam harus ditolak atau jika tidak dimodifikasi supaya cocok dengan Islam.

Pendukungnya banyak mengangap bahwa demokrasi pertama adalah produk asing. Sebagian mereka berargumen bahwa demokrasi, artinya pemerintahan rakyat ("rakyat" sering dipahami sebagai lawan "Tuhan"), mutlak bertentangan dengan doktrin Islam bahwa pemerintah (hukumah) semata-mata berada di tangan Tuhan. ${ }^{17}$ Dalam salah satu tulisannya, Natsir denan hati-hati menerima demokrasi. Dia berargumen bahwa ada beberapa hal dalam islam yang dianggap final, isu-isu seperti pelarangan perjudian dan pornografi tidak bisa dibahas atau di -vote di dalam parlemen. DPR tidak punya hak membahas hal-hal itu.

Pemahaman konsep tersebut memainan peranan sangat penting dalam membentuk sikap mereka terhadap isi-isu religious-politik. Dengan memahami demokrasi sebagai konsep yang dibatasi aturan ilahi, mereka memberikan lebih banyak ruang kepada otoritas relegius. Ini terlihat, misalnya, pada fakta bagaimana mereka mengorbankan beberapa prinsip demokrasi (seperti kesetaraan politik) demi doktrin agama yang, kata mereka, "tidak bisa didiskusikan di parlemen". Misalnya, masalah kewarganegaraan. Doktrin politik Islam klasik mengakui pembagian komunitas politik ke dalam Muslim dan dhimi. Pembedaan ini bukan sekedar identitas politik, tetapi pinya konsekuensi bagi hak-hak dan kewajiban politik. Karena itu, dhimi diharuskan membayar pajak lebih daripada yang dibayarkan muslim.

Namun, tidak semuua pandangan religious-politik pendukungnya sejalan dengan doktrin islam klasik. Dalam kasus lain mereka mengakui pandangan "liberal". Mengenai isu-isu kepemimpinan perempuan, mislanya, sebagain besar mereka setuju bahwa perempuan bisa menjadi pemimpin politik dalam jabatan apa pun, termasuk kepala Negara.

\section{Kesimpulan}

M. Natsir adalah sosok negarawan, pemikir modernis, dan sekaligus mujahid dakwah. Gagasannya yang terkenal adalah mengenai Islam dan negara (demokrasi), Islam dan pancasila, serta tentang dakwah. Gagasan M. Natsir mengenai Islam, negara, dan politik ini dapat dikategorikan sebagai pandangan yang moderat. Dalam arti, ia tidak mengharuskan segala sesuatu kepada tradisi sejarah Islam yang pernah ada. Berkaitan dengan kepala negara, ia amat luwes, tidak mengharuskan khalifah, presiden atau amirul mu'minin. Baginya, yang terpenting adalah berjalannya ajaran

${ }^{17}$ Doktrin politik yang mengatakan pemerintah hanya menjadi milik Allah sebetulnya adalah pandangan Khawarij. Namun, Muslim revivalis memakai jargon yang sama untuk mempertahankan pandangan politik mereka bahwa agama dan politik harus disatukan. Pandangan mendasar Model ini sebetulnya serupa dengan pandangan Khawarij dan pandangan Muslim revivalis. Namun, dalam formulasi kemudian, mereka agak "merasionalisasi" pandangan politik ini dengan memodifikasi baik pandangan utama mereka maupun konsep baru yang mereka hadapi. Hamid Enayat dengan fasih membahas hubungan ideologis antara Khawarij dan gerakan revivalis Islam. Lihat bukunya, Modern Islamic Political Thought (Austin:University of Texas Press, 1982), h. 6-7. 
Islam di tengah-tengah masyarakat. Berdasarkan hasil penelitian tersebut dapat dsimpulkan bahwa corak dakwah yang dikembangkan oleh Moh. Natsir adalah bercorak religius-politik.

\section{Referensi}

Abdul Munir Mulkhan, Ideologisasi Gerakan Dakwah Episod Kehidupan M. Natsir dan Azhar Basyir (Yogyakarta: Sippress, 1996).

Abied, Aunul Shah M. et al. Islam Garda Depan; Mosaik Pemikiran Islam Timur Tengah. Cet. I.( Mizan: Bandung, 2001).

Amien Rais, "M. Natsir the Second Grand Old Man", dalam Pak Natsir 80 Tahun (Jakarta: Media Dakwah, 1988).

Didin Saefudin, Pemikiran Modern dan Post Modern Islam (Jakarta: Gramedia Widia Sarana Indonesia, 2003).

Hamid Enayat, Modern Islamic Political Thought (Austin:University of Texas Press, 1982).

Mohammad Natsir, Fiqhud Da'wah (Jakarta: Media Dakwah, 2000).

Mohammad Natsir, Islam Sebagai Dasar Negara (Jakarta: DDII, 2000).

Yusril Ihza Mahendra, Modernisme dan Fundamentalisme dalam Politik Islam (Jakarta: Paramadina,1999). 